\title{
Erratum to: The effect of implantation on scaffoldless three-dimensional engineered bone constructs
}

\author{
Michael J. Smietana • Fatima N. Syed-Picard • \\ Jinjin Ma • Tatiana Kostrominova Ellen M. Arruda • \\ Lisa M. Larkin
}

Published online: 23 October 2009

(C) The Society for In Vitro Biology 2009

\section{Erratum to: In Vitro Cell.Dev.Biol.-Animal \\ DOI 10.1007/s11626-009-9216-3}

This article, which was published in Volume 45, Number 9, October 2009, pp. 512-522, has the following correction: On page 514, right-hand column, 2nd paragraph, 9th line, change " $2 \mu \mathrm{g} / \mathrm{ml}$ " to " $2 \mathrm{ng} / \mathrm{ml}$ ".

The online version of the original article can be found under http://dx. doi.org/10.1007/s11626-009-9216-3.

\section{J. Smietana $\cdot$ L. M. Larkin}

Biomedical Engineering, University of Michigan,

2025 BSRB, 109 Zina Pitcher Place,

Ann Arbor, MI 48109-2200, USA

F. N. Syed-Picard

Materials Science and Engineering, University of Michigan,

2025 BSRB, 109 Zina Pitcher Place,

Ann Arbor, MI 48109-2200, USA

T. Kostrominova $\cdot$ L. M. Larkin $(\triangle)$

Molecular and Integrative Physiology, Biomedical Engineering,

University of Michigan,

Biomedical Science Research Building (BSRB),

109 Zina Pitcher Place, Room \#2025,

Ann Harbor, MI 48109-2200, USA

e-mail: llarkin@umich.edu
J. Ma • E. M. Arruda

Mechanical Engineering, University of Michigan, 2250 GG Brown, 2350 Hayward, Ann Arbor, MI 48109, USA

E. M. Arruda

Program in Macromolecular Science and Engineering, University of Michigan, 2250 GG Brown, 2350 Hayward,

Ann Arbor, MI 48109, USA

\section{T. Kostrominova}

Department of Anatomy and Cell Biology,

Indiana University School of Medicine-Northwest, Gary, IN 46409-1008, USA 